\title{
Toxicity bioassays with freshwater and wastewater applied to environmental forensic investigation
}

\author{
Rodrigo Henrique Alves e Arnola Cecília Rietzler \\ Ecotoxicology Laboratory, Department of General Biology, Institute of Biological Sciences, Federal University of Minas Gerais, \\ Belo Horizonte, Minas Gerais, Brazil
}

Recebido: 25/01/14 - revisado: 04/04/14 - aceito: 19/05/14

\begin{abstract}
Environmental forensic investigation is an area that still lacks adequate methodologies for the effective fulfillment of its purpose. This study evaluated the application of ecotoxicity bioassays in environmental forensic investigation related to water pollution. Samples were collected from streams in a municipality located in the south central region of the state of Minas Gerais, Brazil, receiving tannery effluents suspected of causing water pollution. This study included acute and chronic toxicity bioassays in water and tannery effluent samples, using microcrustaceans as bioindicators, as well as dosage of chromium, cadmium and lead in samples. Toxic effects on survival and reproduction of organisms were detected, which were related to bigh concentrations of chromium in the samples, reaching up to $3955.0 \mathrm{mg}$.Kg-1. The ecotoxicological assessment showed a high potential for application in Environmental Forensic Investigation, as it provided robust evidence of the impact of the assessed activities on bioindicators of aquatic fauna.
\end{abstract}

Keywords: Environmental forensics. Tannery wastewater. Chromium. Ecotoxicological assessment of freshwater and wastewater

\section{INTRODUCTION}

There is greater environmental awareness in society today, which has generated a growing demand from governments for measures aimed at the protection, prevention and repression of aggressions against the environment (BRASIL, 1998). Notably, aquatic pollution has become a global problem in recent years, which is particularly related to extensive industrialization (SREENIVASAN; KRISHNA MOORTHY, 2011).

The potential mobilization of toxic trace metals and metalloids in the environment can be considered the most dangerous forms of pollution. Chromium is among the most important elements related to this, whose adverse toxic effects are recognized. This element is highly toxic and carcinogenic to human beings, animals, plants (BELAY, 2010). This metal may be present naturally in low concentrations in aquatic ecosystems, without compromising the environment (JORDÃO et al., 1999). Human activities can act as a source of contamination, as chemical industry, electroplating, production of paints and pigments, tanning, wood preservation, chromium chemicals production, metal smelting, and pulp and paper production (ZHITKOVIC, 2011). However, it is the major constituent of tannery effluent, which is highly toxic to aquatic fauna (SREENIVASAN; KRISHNA MOORTHY, 2011).

Tannery wastewaters are highly complex and are characterized by high contents of organic and inorganic compounds, including toxic substances such as sulfides and chromium salts (DURAI; RAJASIMMAN, 2011). The tanning industry is one of the most polluting industries, even after the emergence of concerns about its environmental control (JORDÃO et al., 1999).

Due to this potential danger, the level of chromium in wastewaters must be reduced to a permissible limit before discharging into natural water bodies (GEBREKIDAN et al., 2009). All concerned organizations and governments have to work together to reach at least the chrome discharge limit (BELAY, 2010). Although the Brazilian government is improving its environmental legislation, infrastructure problems are still important obstacles. To deal with these difficulties, environmental regulations with law enforcement are necessary to stimulate the use of better treatment systems. Polluter pay or precautionary principles must also be applicable to these polluter industries (BELAY, 2010).

With respect to the development of environmental legislation in Brazil, the main advance was the Law No. 9605 of 1998, known as the "Environmental Crimes Law" (BRASIL, 1998), after which the need for actions from public security organizations has been established. Its Forensic Sections are responsible for the survey of evidence related to environmental crimes. However, since it is not a traditional area of forensic sciences, it is necessary to develop procedures in this context for the obtainment of accurate scientific evidence for specific crimes listed in this law, as is the case of pollution impacts (BARBIERI et al., 2007).

Few studies based on scientific methods have been devoted to environmental forensics in Brazil, even less related to pollution caused by tanneries. One of these few studies was conducted by Barbieri et al. (2007) who carried out an environmental crime investigation in a landfill site containing hazardous waste of tannery and shoe factories, in Arroio do Meio, Rio Grande do Sul, Brazil. This study involved the quantification and characterization of the probable pollution, through analyses of animal tissues, water, and sediment samples, associated with data from preexisting analyses in biotic and abiotic compartments.

In relation to Minas Gerais, few studies related to pollution caused by tanneries have been carried out. Although not related to an environmental criminal investigation, one of the most relevant ones was conducted by Jordão et al. (1999), showing chromium contamination in streams located near tan- 
neries in Minas Gerais. In this context, it is essential to develop methods applicable to environmental forensics related to such impacts, as part of its control.

The toxic effects of only a small part of known chemical substances have been described (ZHITKOVIC, 2011) increasing the difficulty of solving environmental problems, including the process of obtaining physical evidence of suspected pollution impacts.-In this context, Ecotoxicology has proved to be very promising in monitoring the effects of human activities, since it evaluates the toxic effect on organisms, resulting from all substances present at the site where they are located, characterizing the damage to their vital functions and mortality through toxicity tests (ESCHER et al., 2011).

Toxicity tests with aquatic organisms can be an effective tool for assessment, prediction or detection of the effects of pollutants on living organisms (MATEJCZYK et al., 2011). Standard methods have been developed to evaluate the toxicity of contaminants using such organisms as amphipods, midges, oligochaetes, polychaetes, insects and cladocerans. Several parameters are suggested in these methods, including survival, growth, behavior and reproduction (BEYER et al., 2014).

Ecotoxicological parameters have been added to the general legislation applicable to water quality in Brazil, in the Resolution 357/05 of the National Environmental Council CONAMA (BRASIL, 2005). It specifies that in Class I and II freshwaters, chronic toxic effects cannot be detected, while in Class III there should be no acute toxic effect. Toxicity criteria should be defined based on the results of standardized ecotoxicological tests, using aquatic organisms and performed on effluents. The standard also requires that States adopt specific criteria, as well as indicate the analytical methods for the establishment of criteria. For example, São Paulo State established ecotoxicological control of wastewaters through Resolution SMA-03/2000 (SÃO PAULO, 2000), regulating industrial effluent toxicity. However, in Minas Gerais State there is still no specific resolution for industrial wastewaters.

Thus, considering that more research on contamination by chromium from tannery wastewaters in aquatic ecosystems should be developed (JORDÃO et al., 1999), and the potential of ecotoxicological studies in such an approach, the present study aimed to evaluate the application of acute and chronic toxicity assays for the detection of water pollution caused by the discharge of tannery effluents into water bodies. This study highlights the need for adequate standardized protocols in environmental forensics using a biological tool to track sources of contamination, focusing on the assessment of harmful effects of tannery wastewaters on aquatic fauna bioindicators.

\section{MATERIAL AND METHODS}

\section{Study area}

The study area involved two water flows, the main and its tributary stream, both receiving effluents from tanneries in an extensively disturbed area on the outskirts of the urban area of a central-southern municipality of the state of Minas
Gerais, Brazil.

Water samples for the preliminary assays were collected in September 2007 (dry season), in two sites suspected of contamination (P2 and P3), and in a reference site (control - CC). In March (rainy season), and in August (dry season) of 2008, three other suspected sites of contamination (P1, P4 and P5) were added to those previously defined for the preliminary assays.

As shown in Figure 1, CC and P2 samplings sites are in the tributary stream, while P1, P3, P4 and P5 are in the main stream. P2, P3 and P4 correspond to sites receiving discharge of tannery effluents. CC and P1 are located upstream from the tannery effluent discharges and P5 is located downmost of all.

\section{Toxicity assays and tests}

Acute and chronic toxicity assays, using Daphnia laevis, Daphnia similis and Ceriodaphnia silvestrii, were performed according to ABNT (2004, 2005), respectively. The endpoint for the acute effect was immobility of individuals, after 48 hours, and, for chronic toxicity assays, reproduction in a period of 8 days. Before the assays were performed, sensitivity tests were carried out using $\mathrm{NaCl}$ as reference substance. Chemical parameters including $\mathrm{pH}$, dissolved oxygen (DO in $\mathrm{mg} \cdot \mathrm{L}^{-1}$ ), conductivity $\left(\mu \mathrm{S} . \mathrm{cm}^{-1}\right)$ and water hardness $\left(\mathrm{mg} . \mathrm{L}^{-1} \mathrm{CaCO}_{3}\right)$ were also monitored during the tests.

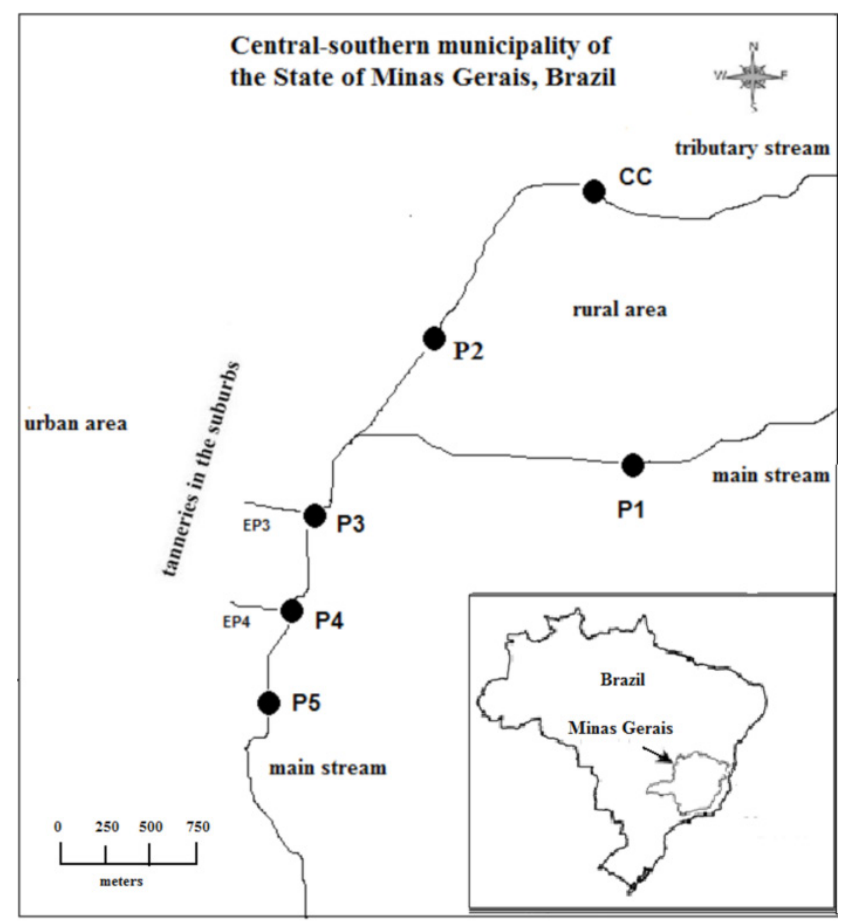

Figure 1 - Sampling sites located in the central-southern region of Minas Gerais State, Brazil

Moreover, samples from two tannery effluents (EP3 and EP4), discharged at sites P3 and P4 in the main stream, were collected during the period intermediate between the rainy and dry seasons of 2008. The ecotoxicological effluent control methodology was applied to these samples, taking Resolution 
SMA-3/2000 for São Paulo State as reference (SÃO PAULO, 2000). The latter regulates industrial effluent toxicity through acute and chronic tests using $D$. similis and $C$. silvestrii, with multiple concentrations of the effluents, in order to determine the EC50 and CENO, respectively. Toxic Units and Toxic Loads of these two effluents were also estimated.

Toxic Units and Toxic Loads were evaluated considering that toxicity and acute toxicity values, expressed as EC50, exhibit an inverse relationship. With respect to Toxic Units (TU), where $\mathrm{TU}=100 / \mathrm{EC} 50$, the toxicity is expressed through a direct relationship. The TU multiplied by the flow of the effluent (in L. $\mathrm{s}^{-1}$ ) provides an estimate of the toxic load in the effluent ((Nieto 2000). According to these authors, the comparative analysis of the toxic load of all effluents in the same water basin can identify which industries contribute more as a source of pollution for the receiving water bodies.

The results of the toxicity assays were statistically analyzed using methodology adapted from USEPA (2002a, b) .

\section{Chemical analyses}

During the dry season of 2008, CC, P1, P2, P3, P4 and P5 freshwater samples and EP3 and EP4 tannery wastewater samples were collected, preserved and analyzed at the Centre for Development of Nuclear Technology, Belo Horizonte, Minas Gerais, Brazil. The preserved samples were dried and the total solids were analyzed by an EDX-720 Energy-dispersive X-ray spectrometer - Shimadzu to measure $\mathrm{Cr}, \mathrm{Cd}$ and $\mathrm{Pb}$ concentrations, metals commonly associated with tannery wastewaters. Samples were also filtered for removal of suspended solids. The filtrate, containing only dissolved solids, was analyzed in terms of its concentration of $\mathrm{Cr}, \mathrm{Cd}$ and $\mathrm{Pb}$ and $\mathrm{Cu}$ in $\mathrm{ppm}$, by the method of atomic absorption spectrophotometry.

\section{RESULTS}

\section{Toxicity assays and tests}

The results for the sensitivity tests using $\mathrm{NaCl}$ as reference substance were between $1.3-2.8 \mathrm{mg} \cdot \mathrm{L}^{-1}$, for $D$. similis, $1.6-2.3 \mathrm{mg} . \mathrm{L}^{-1}$ for D. laevis and 1.14 - $1.91 \mathrm{mg} . \mathrm{L}^{-1}$ for $C$. silvestrii, showing that the organisms were in good condition for use in toxicity bioassays. The difference in sensitivity between the organisms emphasized the importance of using more than one species in bioassays.

Results of the acute toxicity assays are shown in Table 1. For $D$. similis, there was a statistically significant difference between CC and P3 in the dry season of 2007 ( $p=0.03$ ), and between CC and P3 ( $<<0.05)$, P4 ( $=0.01)$ and P5 ( $<<$ 0.05 ) for the dry period of 2008. For D. laevis, we observed the same results as obtained for D. similis during the dry season of 2008, with additional detection of toxicity effects for samples from P2 $(\mathrm{p}<0.05)$. The most severe effects were detected at the sites where effluents from tanneries were discharged (P2, P3 and P4). Moreover, it was found that the toxic effects extended beyond the discharge sites of these effluents (P5).
Table 1 - Percentage of immobility of $D$. similis and D. laevis, in acute toxicity assays with freshwater samples

\begin{tabular}{cccccc}
\hline \multirow{2}{*}{ Se } & \multirow{2}{*}{ Sa } & \multicolumn{2}{c}{ D. similis } & \multicolumn{2}{c}{ D. laevis } \\
\cline { 3 - 6 } & & Im (\%) & AT & Im (\%) & AT \\
\hline \multirow{2}{*}{$\begin{array}{c}\text { 2007 } \\
\text { (dry) }\end{array}$} & CC & 0 & Control & - & - \\
& P2 & 5 & No & - & - \\
& P3 & 15 & Yes & - & - \\
\hline & CC & 0 & Control & 0 & Control \\
& P1 & 0 & No & 10 & No \\
& & & No & 10 & No \\
2008 & P2 & 0 & & 10 & No \\
(rainy) & P3 & 0 & No & 10 & No \\
& P4 & 0 & No & 5 & No \\
& P5 & 0 & No & 5 & \\
\hline & CC & 0 & Control & 0 & Control \\
& P1 & 10 & No & 20 & No \\
2008 & P2 & 5 & No & 40 & Yes \\
(dry) & P3 & 100 & Yes & 95 & Yes \\
& P4 & 25 & Yes & 35 & Yes \\
& P5 & 80 & Yes & 65 & Yes \\
\hline
\end{tabular}

Se (Seasons). Sa (Samples). Im (Immobility). AT (Acute Toxity - T Test or Fisher Test). Yes (Toxic effect observed). No (No toxic effect).

With the samples in which no acute effect was detected, chronic toxicity tests with $C$. silvestrii were conducted (see Table 2). A statistically significant difference was found between the number of neonates produced by CC and P2 ( $<<0.05)$ in the dry season of 2007 and between CC and P3 (p = 0.00), P4 (p $=0.00)$ and P5 $(p=0.00)$ in the rainy season of 2008. These results were complementary to those found in the acute toxicity tests, showing that all sampling sites where the tannery effluents are discharged presented toxic effects, acute or chronic, even in the rainy period. Furthermore, effects on the survival of the parentals were detected in P2 samples in the dry season of 2007 ( $\mathrm{p}<0.05)$.

The values of dissolved oxygen (DO) measured in freshwater samples at the start of the toxicity assays were correlated with the standards established by the Brazilian Resolution 357/2000 (Brasil 2005), for Class III water bodies (DO above $4.0 \mathrm{mg} \mathrm{L}^{-1}$ ). The following nonconformities were noted: DO concentration of samples from P3 for the acute and chronic toxicity assays in the dry season of 2007 (0.76 and $1.25 \mathrm{mg} \mathrm{L}^{-1}$, respectively) and DO concentrations of samples from P3, P4 and $\mathrm{P} 5$ in the dry season of $2008\left(1.62 \mathrm{mg} \mathrm{L}^{-1}, 2.2 \mathrm{mg} \mathrm{L}^{-1}\right.$ and $2.76 \mathrm{mg} \cdot \mathrm{L}^{-1}$, respectively). 
Table 2 - Parental survival and total number of neonates of Ceriodaphnia silvestrii in chronic toxicity assays, with freshwater samples

\begin{tabular}{ccccc}
\hline Se & Sa & PS & TN & $\begin{array}{c}\text { Chronic } \\
\text { Toxicity* }\end{array}$ \\
\hline 2007 & CC & Control & 297 & Control \\
(dry) & P2 & Yes & 61 & Yes \\
\hline & CC & Control & 161 & Control \\
& P1 & No & 164 & No \\
& P2 & No & 140 & No \\
2008 & P3 & No & 112 & Yes \\
(rainy) & P4 & No & 90 & Yes \\
& P5 & No & 89 & Yes \\
\hline 2008 & CC & Control & 293 & Control \\
(dry) & P1 & No & 312 & No \\
\hline
\end{tabular}

Se (Seasons). Sa (Samples). Im (Immobility). PS (Parental Survival). TN (Total Neonates). Yes (Toxic effect observed). No (No toxic effect). *(Wilcoxon Rank-Sum Test)

\section{Ecotoxicological control of wastewater}

The concentration - response curves, expressed as immoblity percentage $\mathrm{X}$ concentration, obtained from acute toxicity tests, using samples of EP3 and EP4 effluents are shown in Figure 2. The statistical model indicated the probit method as the most appropriate. This test provided EC50 (48-h) values corresponding to $60.9 \%$ for EP3 and $52.8 \%$ for EP4, the latter therefore being the most toxic.

The concentration - response curves, expressed as number of neonates $\mathrm{X}$ concentration, obtained from chronic toxicity tests, using samples of EP3 and EP4 effluents are shown in Figure 3. The statistical model indicated Dunnett's test as the most appropriate. This test provided CENO values of $10 \%$ for EP3 and 5\% for EP4, the latter again being the most toxic.

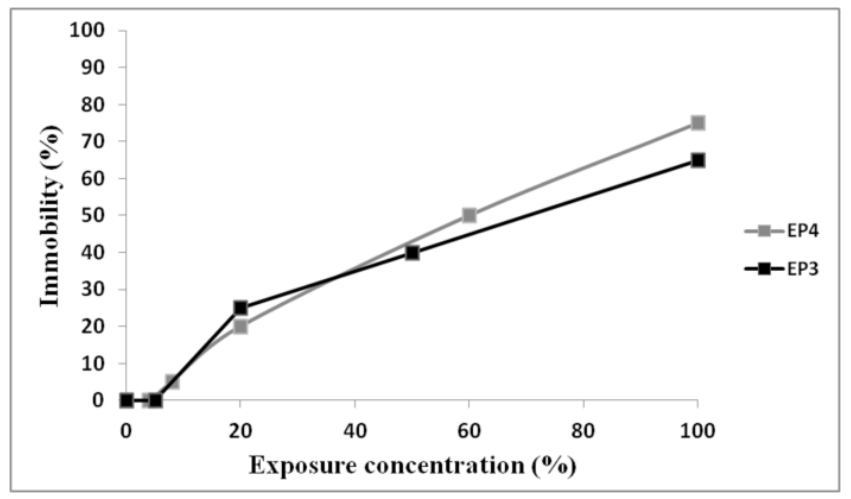

Figure 2 - Percentage of immobility of D. similis in acute toxicity tests with multiple concentrations of EP3 and EP4 effluents

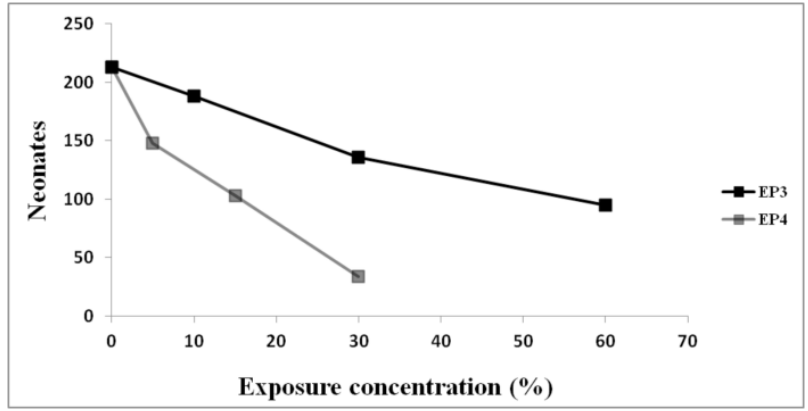

Figure 3 - Number of neonates produced by $C$. silvestrii in chronic toxicity tests with multiple concentrations of EP3 and EP4 effluents

The results of the TU and Toxic Loads of the two effluents can be seen in Table 3. EP4 effluents showed a greater TU. However, since its flow is significantly lower than the flow of EP3 effluents, its Toxic Load was lower.

Table 3 - Toxic Units (TU) and Toxic Load of effluents

\begin{tabular}{ccccc}
\hline Effluent & EC50;48h & $\begin{array}{c}\text { Toxic Units } \\
\text { (TU) }\end{array}$ & $\begin{array}{c}\text { Effluent } \\
\left.\text { flow (L.s }{ }^{-1}\right)\end{array}$ & $\begin{array}{c}\text { Toxic load } \\
\text { (TU x L.s }^{-1} \text { ) }\end{array}$ \\
\hline EP3 & 61 & 1.64 & 284 & 466 \\
EP4 & 53 & 1.89 & 47 & 89 \\
\hline
\end{tabular}

EP3 (Effluent from P3). EP4 (Effluent from P4).

The relation between the dilution data and EC50 values obtained for EP3 and EP4 effluents is shown in Table 4. The values of dilution of effluents in the receptor streams (DER) of the two effluents were higher than their CE50/100, and thus, the results indicated the potential negative impact of both on the receiving water body.

\section{Chemical Analyses}

The results of the chromium concentration in total solids (mg. $\left.\mathrm{Kg}^{-1}\right)$ from the freshwater and EP3 and EP4 wastewater samples are shown in Table 4 . This analysis did not detect the metals $\mathrm{Cd}$ and $\mathrm{Pb}$.

Table 4 - Impact evaluation of Effluents EP3 and EP4 in the receptor stream, through the relationships between DER and EC50 values

\begin{tabular}{cccccc}
\hline E & $\begin{array}{c}\text { CE50; } \\
\mathbf{4 8 h / 1 0 0}\end{array}$ & $\begin{array}{c}\text { EF } \\
\left(\mathbf{L . s} \mathbf{s}^{-1}\right)\end{array}$ & RSF (L. s $\left.{ }^{-1}\right)$ & DER* (\%) & $\begin{array}{c}\text { Potential } \\
\text { Impact }\end{array}$ \\
\hline EP3 & 0.6 & 284 & 148 & 66 & Yes \\
EP4 & 0.5 & 47 & 149 & 10 & Yes \\
\hline
\end{tabular}

E (Effluent). EF (Effluent Flow). RSF (Receptor Stream Flow).

* Dilution of effluents in the receptor streams. Yes (Potential Impact detected).

Chromium was bellow the limit of detection at the control site (CC), located in the tributary stream and at the first sampling point in the main stream, P1, located upstream of the discharge of effluents from tanneries. On the other hand, P2, 
the other site of this tributary stream, receiving discharge of tannery effluents, presented moderated concentrations. The other sampling sites in the main stream, also receiving tannery effluent discharges (P3 and P4), showed an increasing trend in concentration of chromium, followed by a decrease at P5, located downstream from these discharges.

The elementary chemical analyses of the total solids of the EP3 and EP4 effluents showed a high concentration of chromium only in EP4 effluents (see Table 5).

Table 5 - Dosage of chromium in total solids of freshwater and wastewater samples by $\mathrm{x}$-ray fluorescence spectroscopy

\begin{tabular}{ccccccccc}
\hline $\begin{array}{c}\text { Metal** } \\
\text { mg.Kg }\end{array}$ & \multicolumn{1}{c}{ Samples } \\
\hline $\mathrm{Cr}$ & CC & P1 & $\mathbf{P} 2$ & P3 & P4 & P5 & EP3 & EP4 \\
\hline
\end{tabular}

* Bellow the limit of detection $\left(7.0 \mathrm{mg} \cdot \mathrm{Kg}^{-1}\right) .{ }^{* *} \mathrm{Cd}$ and $\mathrm{Pb}$ bellow this limit in all samples.

Results of the analysis of the filtrate by atomic absorption spectrophotometry showed that concentrations of metals were below the limit of detection of this method $(0.1$ ppm), including chromium. These results, combined with the evaluation of total solids indicated that the chromium present in the samples was essentially linked to the suspended solids from the water. However, these results were not comparable with standard limits stipulated in mg.L $\mathrm{L}^{-1}$, by CONAMA Resolution 357/2005 (BRASIL 2005).

\section{DISCUSSION}

The ecotoxicological assessment showed the worst results for the sites where tanneries effluents were launched (P3 and P4), and downstream it (P5). In general, water samples of these environments showed acute toxicity to $D$. similis and $D$. laevis and chronic toxicity to $C$. silvestrii, at least in one of the three periods evaluated. Moreover, the toxic effects observed at P5, located downstream from the effluent discharges, indicated impact beyond the locations where effluent discharges occurred.

Corroborating these findings, several studies have shown toxicity caused by tannery wastewater to many species. Among the toxic effects, Sreenivasan e Krishna Moorthy (2011) found structural alterations of liver and muscle in Tilapia mossambica that were attributed to the sublethal effect of chromium from tannery effluents. Taju et al. (2012) conducted cytotoxic and acute bioassays with the fish Etroplus suratensis exposed to tannery effluent and found that the toxic effect on the survival of fish was concentration and time dependent.

Tannery wastes may also cause genotoxic, immunotoxic and bioaccumulative effects. Murugesan et al. (2012) reported immunotoxic effects on the fish Cyprinous carpio in chronic exposure to sub-lethal concentrations of tannery effluent, involving the humoral antibody response and the cell-mediated immune response. Lemke-de-Castro et al. (2010) demonstrated that the use of tannery effluents in agriculture soils may pose a potential risk to humans as well as animals through bioaccumulation from one trophic level to the next, besides risk of contamination of groundwater.

The acute toxic effects found in the present study occurred in the dry seasons probably due to a greater concentration of contaminants, while chronic effects occurred in the rainy season, when such contanimants were more diluted. The differences between the results of the two dry seasons may be related to seasonal variations and/or cyclic variations of the discharges of effluents into the water bodies analyzed.

The chromium data corroborated the results of the assays at the studied area, since this metal was found in increasing concentration levels at the sampling sites with discharges of effluents from tanneries (P2, P3 and P4), being also detected downstream (P5). In addition, a high concentration of chromium was found in EP4 effluents (3955 mg. $\mathrm{Kg}^{-1}$ ).

These results were close to the high values of chromium also found by Jordão et al. (1999) in water samples of streams located near tanneries in Minas Gerais State, showing chromium concentrations in suspended material ranging from 15 to 11066 $\mu$ g.g-1, with chromium concentrations 656 times greater than the value established by the Brazilian environmental standards. Chromium contamination was also found in fishes from rivers that received tannery discharges in Minas Gerais, with chromium levels 35 times greater than the Brazilian recommendation value for human intake (JORDÃO et al., 1997). Taju et al. (2012) also reported that tannery effluents showed extremely toxic effects to fishes. According to them, tannery effluent at the concentration of $15 \%$ caused $100 \%$ mortality at $96 \mathrm{~h}$ whereas the lower concentration $(0.5 \%)$ caused $13.33 \%$ mortality.

Other substances in the tannery effluents besides chromium could have contributed to the observed toxicity, such as ammonia and chloride, as well as the interactions between chromium and the other effluent compounds (COOMAN et al., 2003).

As metal ions enter the environment, their chemical form largely determines their potential toxicity (GEBREKIDAN et al., 2009). The physicochemical form of the chromium determines its toxicity potential in natural waters, due to the different toxicity of chromium states and free hydrated metal ions as compared to stable complexes of these ions. In natural waters, the trivalent and hexavalent forms are described as the two stable oxidation states of $\mathrm{Cr}$, which have different toxicities, motilities, and bioavailability. The trivalent form is naturally predominant and is considered to be significantly less toxic, although it can be oxidized to hexavalent chromium (BELAY, 2010).

Chromium has been described to be fully speciated in the final tannery effluent, the discharge plume, and in the receiving waters. It was shown that the hexavalent chromium species was unstable in tannery wastewaters and only a small part of the trivalent chromium, the dominant form, was ionic and, thus, particularly toxic. Most of the trivalent chromium was associated with macromolecular particles in complexed or colloidal forms, mainly inorganic compounds, with a minority bound to organic ligands (SREENIVASAN; KRISHNA MOORTHY, 2011). 
Due to adsorption, hydrolysis and co-precipitation, only a small portion of free metal ions stay dissolved in water and a large quantity of them get deposited in the sediment that may act as a sink and a source of pollution. It has been shown that the concentration of dissolved trivalent $\mathrm{Cr}$ falls by half after the lowering of the $\mathrm{pH}$ of the final effluent in the receiving waters. However, the presence of organic matter increases the trivalent chromium solubility when the relative abundance of organic ligands exceeds a threshold. It has also been reported that $\mathrm{Cr}$ in water was significantly correlated with dissolved $\mathrm{Cl}^{-}$, $\mathrm{Fe}$ and $\mathrm{Mn}$ in small tributaries where tannery effluent had been discharged (BELAY, 2010; ESCUDERO et al., 2013; MOHAMED et al., 2013). In the present study, chromium speciation in the sampling sites could be influenced by these parameters which, however, were not analyzed.

According to CONAMA Resolution 357/2005 (BRASIL, 2005), acute toxic effect should not be detected for Class III water bodies, according to the criteria established by the competent environmental agency, or in its absence, by nationally or internationally renowned agencies as indicated by standardized procedures for ecotoxicological assays or other scientifically recognized methods. In the present study, there was disagreement with the resolution quoted, given the acute toxic effect detected for $D$. similis and D. laevis, both in tributary (P2) and main stream samples (P3, P4 and P5). However, it is not possible to affirm with precision the origin of the pollution, using only samples of the receiving water bodies. This is the same problem that occurs when chemical analyses are carried out only on samples from receiving water bodies.

CONAMA Resolution 357/2005, in its Article 34, establishes that effluents from any source of pollution can only be released directly or indirectly into water bodies if they do not cause, or do not have the potential to cause, toxic effects to aquatic organisms in the receiving water body, according to toxicity criteria established by the environmental agency. This resolution points out that the toxicity criteria should be based on results of standardized ecotoxicological assays using aquatic organisms and performed with effluents.

The Environmental Crimes Law (BRASIL, 1998) defines that inconformities with the regulating legislation (CONAMA Resolution 357/2005) may also characterize a pollution crime. The application of the ecotoxicological control method for effluents, following these resolution criteria, found a potential negative impact of both effluents, (EP3 and EP4) on the main stream. Thus, this method detected an inconformity with this resolution. It showed the great ability of this technique to provide proof in investigations of water pollution by effluent discharges and was, therefore, suitable for the environmental forensics approach.

Moreover, of all the methods used in this study, ecotoxicological control of effluents seems to be the most powerful method in environmental forensics, when the focus is to track sources of water pollution by effluent discharges, since it allows the identification, at specific sites, of the impact of effluents on the receiving water body. It thus avoids the contestation of evidence that could arise if assays were carried out with water samples collected after the discharge of the effluents, since one could argue that such an effect could arise from other sources of discharges released upstream. It still lacks, however, specific control legislation for Minas Gerais State, so that the legislation for ecotoxicological control of effluents of São Paulo State was used in the present study.

At a human point of view, drinking water supplies in many places in the world contain Cr (III) and Cr (VI) and public health concerns are centered mainly on the presence of hexavalent form that is classified as a known human carcinogen. Extensive DNA damages showed in genotoxicity assays, associated to carcinogenicity, strongly support the importance of controlling Cr (VI) in water resources (ZHITKOVIC, 2011).

As in Brazil, other countries have made efforts regarding the assessment of the potential risks of chemicals. There is a growing awareness that the reduction of chemical pollution will have to integrate the environmental standards established for water, and the standards set for chemicals, as is the case of Directive 2000/60/EC, in the European Community and EPA standards, in United States. The selection of priority substances is done through risk assessment methodologies, including the risk assessment based on aquatic ecotoxicity and human toxicity (EC 2000) (ZHITKOVIC, 2011). According to Belay (2010), considering the conventional treatment plant used by the tanning industry, reaching the EPA standard limits for chromium is not practical in most of the cases, due to the high amounts of this metal in its wastewater.

Changes in technology and research are needed to control or to eliminate the sources of contamination and to understand and minimize the impact of pollutants already present in the environment. Given the serious impacts on ecosystems and even on human health related to chromium, it is crucial that effluents containing this metal be treated prior to their release into the environment, such as is the case with the leather industry (BELAY, 2010; ESCUDERO et al., 2013).

Treatment of tannery wastewater is carried out by physical, chemical or biological methods or a combination of them, offering different efficiencies (DURAI; RAJASIMMAN, 2011). In some cases, toxicity is much reduced after the treatment, while in others, toxicity removal is inefficient. According to these authors, it is observed that most treatment systems for tannery effluents reduce their toxicity, although there are cases where the treated effluents are as toxic as or even more toxic than the untreated effluents. Among successful examples, Nieto (2001) showed a significant reduction of toxicity of four leather effluents treated by conventional wastewater treatment, corresponding to 86.1 , 94.2, 95.6 and $99.8 \%$ reductions as compared to raw sewage. Similarly, Escudero et al., 2013 showed a significant chromium removal from aqueous solutions.

All these studies have found that it is possible to reduce the harmful effects of effluents containing chromium. The contamination of water sources by this pollutant, especially in tanning activities, can be attributed to carelessness or negligence of those responsible for such activities, resulting in a possible criminal prosecution. Previously dependent upon a forensic environmental test to determine if an activity causes environmental damage, the testing and toxicity testing of water samples as well as effluents suspicious of contaminating water bodies can be 
a tool for application in those cases, as shown in the present study. It raises the possibility for application of ecotoxicological assays with samples from various environmental compartments, providing information on impacts to the biota through results that can represent objective, strong and enlightening proof in environmental crime investigations.

It is essential that the bioindicators used in the assays and tests be standardized, so as to ensure the suitability of the test. Within this perspective and considering the universe of tests applied in the ecotoxicological assessment in this study, the acute toxicity test using Daphnia similis was considered the most suitable to provide evidence, since $D$. laevis is not standardized yet in Brazil, although it is a native species.

Most studies on environmental forensics related to pollution cases by trace elements suggest the use of chemical analyses of these elements in water (LENG et al., 2013; BARBIERI et al., 2014), sediments and soils samples (ARROYO et al., 2010; FANG; YANG, 2010; PAPASTERGIOS et al. , 2010, IWEGBUE, 2013) and industrial products (LAN et al., 2013). Some studies in this area include biological parameters, although they usually propose the monitoring of the concentration of contaminants and toxins in organisms (GURBUZ et al., 2012; REJOMON et al., 2012; CHO et al., 2013; SHIRNESHAN et al., 2013; ZHAN et al., 2013). All these authors proposed the use of this method for forensic investigations. However, further studies evaluating the effect of heavy metals on the species applied to environmental forensics are needed.

The ecotoxicological assays carried out in the present study required relatively short duration, lower costs and practical proceedings compared to the traditional chemical analyses approach. Sampling was simple and the results showed satisfactory reliability. These are desirable methodological features for environmental forensics investigations.

In the present study, we used three species of organisms. Further studies are recommended to explore other ways of assessing the impact of effluents on water quality, including other techniques and bioindicators, in order to identify more robust methods for obtaining proof suitable for environmental forensics. Among the new approaches, the application of mutagenic, genotoxic and toxicity assays with other organisms and other environmental compartments are suggested, including methodologies that balance shorter duration, lower costs and greater reliability.

\section{CONCLUSIONS}

P2, P3, P4 and P5 water samples showed acute toxicity to $D$. similis and D. laevis and P3, P4 and P5 water samples showed chronic toxicity to $C$. silvestrii. In general, acute toxic effects were detected in the dry season while chronic toxic effects were detected in the rainy season.

The high chromium concentrations detected in the samples from stream sites of discharge of tannery wastewater (P2, P3 and P4) as well as the samples of tannery effluent (EP4) indicated this metal as the most probable cause of toxicity.

The ecotoxicological control method for effluents de- monstrated the potential negative impact of tannery effluents on water bodies, being able to provide robust proof for environmental forensics, in investigations of water pollution by effluent discharges.

The ecotoxicological assays can be used for rapid and accurate tracking and monitoring of water pollution by tannery effluents and other anthropogenic sources of water contamination. They can provide proof in environmental forensic investigations, with the benefits of sampling simplicity, analytical practicality and reduced time required for the assays.

\section{ACKNOWLEDGEMENT}

The authors would like to thank Zilmar Lula from Centre for Development of Nuclear Technology, Belo Horizonte, Brazil, for helping with chemical analyses, and Dr. Kennedy Roche for his improvements of an earlier draft.

\section{REFERENCES}

ABNT - ASSOCIAÇÃO BRASILEIRA DE NORMAS TÉCNICAS, NBR 12713 - Ecotoxicologia aquática Toxicidade aguda - Método de ensaio com Daphnia spp (Crustácea, Cladocera). Rio de Janeiro, ABNT, 2004. 21p.

ABNT - ASSOCIAÇÃO BRASILEIRA DE NORMAS TÉCNICAS, NBR 13. 373 - Ecotoxicologia aquática Toxicidade crônica - Método de ensaio com Ceriodaphnia spp. (Crustácea, Cladocera). Rio de Janeiro, ABNT, 2005. 13p.

ARIS, A. Z.; PRAVEENA, S. M.; ISA, N. M.; LIM, W. Y.; JUAHIR, H.; YUSOFF, M. K.; MUSTAPHA, A. Application of environmetric methods to surface water quality assessment of Langkawi Geopark (Malaysia). Environmental Forensics, v.14, n.3, p.230-239. 2013.

ARROYO, L. A.; TREJOS, T.; HOSICK, T.; MACHEMER, S.; ALMIRALL, J.; GARDINALI, P. Analysis of soils and sediments by Laser Ablation Inductively Coupled Plasma Mass Spectrometry (LA-ICP-MS): an innovative tool for environmental forensics. Environmental Forensics, v.11, n.4, p.315-327. 2010.

BARBIERI, C. B.; SARKIS, E. S.; MARTINELLI, L. A.; BORDON, I. C. A. C.; MITTEREGGER JR.; H., HORTELLANI, M. A. Forensic evaluation of metals (Cr, $\mathrm{Cu}, \mathrm{Pb}, \mathrm{Zn}$ ), isotopes ( $\delta 13 \mathrm{C}$ and $\delta 15 \mathrm{~N})$, and $\mathrm{C}: \mathrm{N}$ ratios in freshwater sediment. Environmental Forensics, v.15,n.2, p.134146. 2014.

BARBIERI, C. B., SCHWARZBOLD, A.; RODRIGUEZ, M. T. R.. Environmental crime investigation in Arroio do Meio, Rio Grande do Sul, Brazil: Tannery and shoe factory waste landfill case study. Environmental Forensics, v.8, n.4, p.361-369, 2007. 
BELAY, A. A. Impacts of chromium from tannery effluent and evaluation of alternative treatment options. Journal of Environmental Protection, v.1,n.1 p.53-58.mar.2010.

BEYER, J., PETERSEN, K., SONG, Y., RUUS, A., GRUNG, M., BAKKE, T.; TOLLEFSEN, K. E. Environmental risk assessment of combined effects in aquatic ecotoxicology: A discussion paper. Marine Environmental Research, v.96, p.81-91. May 2014.

BRASIL (Leis, decretos, etc.) Lei $n^{\circ}$ 9.605. Dispõe sobre as sanções penais e administrativas derivadas de condutas e atividades lesivas ao meio ambiente, e dá outras providências. Diário Oficial da União. Brasília, DF. 13, Fev. 1998.

BRASIL (Leis, decretos, etc.) Resolução Conama no 357, de 17/03/2005. Diário Oficial da União, Brasília, DF. March 18, 2005. n. 53, p.58-63.

CHO, S., KIM, D., PARK, J.-S.; CARLSON, K. Measuring the applicability of biosensors to detect possible terror chemicals in water distribution network. Environmental Forensics, v.14, n.1, p. 69-79. 2013.

DURAI, G.; RAJASIMMAN, M. Biological treatment of tannery wastewater - a review. Journal of Environmental Science and Technology, v.4, n.1, p.1-17. 2011.

EC- EUROPEAN COMMISSION. Directive 2000/60/ CE of the European Parliament. Council of 23 October 2003, establishing a framework for Community action in the in the field of water policy. Official Journal of The European Communities, L327, 1 December 22, 2000.

ESCHER, B. I., LAWRENCE, M., MACOVA, M., MUELLER, J. F., POUSSADE, Y., ROBILLOT, C., ROUX, A.; GERNJAK, W. Evaluation of contaminant removal of reverse osmosis and advanced oxidation in full-scale operation by combining passive sampling with chemical analysis and bioanalytical tools. Environmental Science Technology, v.45, n.12, p.5387-5394. 2011.

ESCUDERO, C., FIOL, N., VILLAESCUSA, I.; BOLLINGER, J.-C. Effect of chromium speciation on its sorption mechanism onto grape stalks entrapped into alginate beads. Arabian Journal of Chemistry, v.1, p.1-10. 2013.

FANG , G.-C.; YANG, H.-C. Heavy metals in the river sediments of asian countries of Taiwan, China, Japan, India and Vietnan during 1999-2009. Environmental Forensics, v. 11, p.201-206.

FANG, G.-C.;YANG, H.-C. Heavy metals in the river sediments of asian countries of Taiwan, China, Japan, India, and Vietnam during 1999-2009. Environmental Forensics, v.11 n.3, p.201-206. 2010.
GEBREKIDAN, A., GEBRESELLASIE, G.; MULUGETA, A. Environmental Impacts Of Sheba Tannery (Ethiopia) Effluents On The Surrounding Water Bodies. Bulletin of the Chemical Society of Ethiopia, v.23, p.269-274. 2009.

GURBUZ, F., METCALF, J. S., CODD, G. A.; KARAHAN, A. G. Evaluation of Enzyme-Linked Immunosorbent Assays (ELISAs) for the determination of microcystins in Cyanobacteria. Environmental Forensics, v.13 n.2, p.105-109.2012.

HUANG, W.-J., LU, Y.M.; YU, W.-L. Toxicity and bioaccumulation of monomethylmercury in freshwater Cyanobacteria: Oscillatoria tenuisa and Microcystis aeruginosa. Environmental Forensics, v.13, n.3, p.255-261. 2012.

IWEGBUE, C. M. A. Chemical fractionation and mobility of heavy metals in solisin the vicinity of asphalt plants in Delta State, Nigeria. Environmental Forensics, v.14, n.3, p. 248-259.2013.

JORDÃO, C. P., PEREIRA, J. L.; JHAM, G. N. Chromium contamination in sediment, vegetation and fish caused by tanneries in the State of Minas Gerais, Brazil. The Science of the Total Environment, v.207,n.1, p. 1-11, nov. 1997.

JORDÃO, C. P., SILVA, A. C., PEREIRA, J. L.; BRUNE, W. Contaminação por cromo de águas de rios provenientes de curtumes em Minas Gerais. Química Nova, v.22, n.1, p.47-52. 1999.

LAN, J., LV, J.; FENG, J. Identification of chrome pigments in paints with Fourier Transform Infrared Spectroscopy (FTIR), confocal raman microscopy, and scanning electron microscope-energy dispersive spectrometer. Environmental Forensics v.14, n.2, p.81-86. 2013.

LEMKE-DE-CASTRO, M. L, BORGES, J. D., OLIVEIRA, L. F. C., RODRIGUES, C., FIGUEIREDO, C. C.; CASTRO, W. J. Sorção de cromo em solos do cerrado goiano, Brasil. Revista Ambiente e Água, v.5, n.2, p.134-143. 2010.

LENG, G., FENG, L., LI, S-B., QIAN, S.; DAN, D-Z. Determination of mercury $(\mathrm{Hg})$ in sediment by a Sequential Injection (SI) system with cold vapor Generation Atomic Fluorescence Spectrometry (CVAFS) detection after a rapid and mild microwave-assisted digestion. Environmental Forensics, v.14, n.1, p.9-15. 2013.

MATEJCZYK, M., PLAZA, G. A., NALĘCZ-JAWECKI, G., ULFIG, K.; ARKOWSKA-SZCZUPAK, A. Estimation of the environmental risk posed by landfills using chemical, microbiological and ecotoxicological testing of leachates. Chemosphere, v.82, n.7, p.1017-1023. 2011.

MOHAMED, R. A., ABDEL-LATEEF, A. M., MAHMOUD, H. H.; HELAL, A. I. Study of chromium speciation in water. Studies in Chemical Process Technology, v.1, n.4, p.75-79. 2013. 
MURUGESAN, A. G., RAMATHILAGA, A., SAMSON PONSELVA, J. K.; DINAGARAN MICHAEL, R. Immunotoxicity of Tannery Effluent to the Freshwater Fish Cyprinous carpio. Bulletin of environmental contamination and toxicology, v.88, n.4, p.639-643. Apr.2012.

NIETO, R. Caracterização Ecotoxicologica de Efluentes Liquidos Industriais - Ferramentas para ações de controle da poluição das águas. In: CONGRESSO INTERAMERICANO DE ENGENHARIA SANITARIA E AMBIENTAL, 27., 2000, Porto Alegre.

PAPASTERGIOS, G., FILIPPIDIS, A., FERNANDEZTURIEL, J.-L., GIMENO, D.; SIKALIDIS, C. Distribution of potentially toxic elements in sediments of an industrialized coastal zone of the northern Aegean Sea. Environmental Forensics, v.11, n.3, p.282-292. 2010.

REJOMON, G., MARTIN, G. D., NAIR, S. M.; CHANDRAMOHANAKUMAR, N. Biomonitoring of trace metal pollution using fishes from the cochin backwaters. Environmental Forensics, v.13, n.3, p.272-283. 2012.

SÃO PAULO (Leis, decretos, etc.), 2000. Resolução SMA-3, de 22-02-2002. Secretaria de Estado do Meio Ambiente. Diário Oficial do Estado de São Paulo. Brasilia, DF, 25 Fev. 2002.

SEMENOV, M. Y., ZIMNIK, E. A.; KHODZHER, T. V. Revealing the origin of solutes in surface water using the relationship between organic and inorganic component concentrations. Environmental Forensics, v.13, n.2, p.154-163. 2012.

SHIRNESHAN, G., BAKHTIARI, A. R., SEYFABADI, J.; MORTAZAVI, S. Bioaccumulation of $\mathrm{cd}, \mathrm{Cu}, \mathrm{Pb}$, and $\mathrm{Zn}$ in oyster (Saccostrea cucullata) from qeshm island coast in persian gulf: implications of Provisional Maximum Tolerable Daily Intake (PMTDI). Environmental Forensics, v.14, n.2, p.163-168. 2013.

SREENIVASAN, R. S.; KRISHNA MOORTHY, P. Biochemical Stress of Chromium in Tannery Effluents on the Fresh Water Fish Tilapia mossambica (Pisces). International Journal of Biological \& Medical Research, v.2, n.3, p.616-620. 2011.

TAJU, G.; MAJEED, S. A.; NAMBI, K. S.; SARATH BABU, V.; VIMAL, S.; KAMATCHIAMMAL, S.; HAMEED, A. S. Comparison of in vitro and in vivo acute toxicity assays in Etroplus suratensis (Bloch, 1790) and its three cell lines in relation to tannery effluent. Chemosphere, v.87, n.1, p.55-61. Mar.2012.

USEPA-U.S. Environmental Protection Agency. Short Term methods for estimating the acute toxicity of effluents and receiving waters to freshwater and marine organisms. Washington, DC. U.S. Environmental Protection Agency. Office of Water. 2002a
USEPA, Short Term methods for estimating the chronic toxicity of effluents and receiving waters to freshwater organisms. Washington, DC. U.S. Environmental Protection Agency. Office of Water. 2002b.

ZHAN, X., XI, T.; ZHOU, P. Indirect competitive immunoassay for mercury ion determination using polyclonal antibody against the Hg-GSH Complex. Environmental Forensics, v.14 n.2, p.103-108. 2013.

ZHITKOVIC, A. Chromium in drinking water: sources, metabolism, and cancer risks. Chemical Research in Toxicolology v.24, n.10, p.1617-1629. 2011.

\section{Bioensaios de toxicidade com água e efluentes apli- cados à pericia criminal ambiental}

\section{RESUMO}

A Perícia Criminal Ambiental é uma área que ainda carece de metodologias adequadas para o efetivo cumprimento da sua finalidade. Este estudo avaliou a aplicação de bioensaios de ecotoxicidade em perícias criminais ambientais relacionadas à poluição aquática. Amostragens foram realizadas em cursos d'água de município localizado na região centro-sul do Estado de Minas Gerais, Brasil, que recebem efluentes de curtumes suspeitos de causarem poluição das águas. O estudo incluiu bioensaios de toxicidade aguda e crônica com amostras de água e de efluentes de curtume, usando microcrustáceos como bioindicadores, bem como dosagem de cromo, cádmio e chumbo nas amostras. Foram constatados efeitos tóxicos sobre a sobrevivência e reprodução dos organismos, os quais estiveram relacionados com altas concentrações de cromo nas amostras, chegando a 3955,0 mg. $\mathrm{Kg}^{-1}$. A avaliação ecotoxicológica apresentou alto potencial de aplicação na Perícia Criminal Ambiental, na medida em que forneceu evidências robustas do impacto das atividades avaliadas sobre representantes da fauna aquática.

Palavras-chave: Perícia criminal ambiental. Efluentes de curtumes. Cromo. Ensaios de toxicidade com água e efluentes 